\title{
SMALL MEDIUM ENTREPRISE'S IN EAST JAVA ARE GOING TO DIGITAL ECONOMY
}

\author{
Muhafidhah Novie *)
}

\begin{abstract}
The purpose of this study were 1) to identified the problem of UMKM in implementing 60.000 UMKM domain program, 2) to determine the regional government (East Java) involvement in tackling each issues that comes while implementing 60.000 UMKM domain program, and 3) to classified the priority case in implementing this program. Researcher uses observation, interview, and focus group discussion (FGD) as her research methods. Researcher used 150 East Java UMKM as her sample representative. The results of this study showed that the regional government (East Java) was taking a crucial involvement in educating UMKM to implement this program eventhought they only have limited mentor. Researcher suggested that the government should collaborating with college in achieving their goals.
\end{abstract}

Keywords: UMKM, Online, Domain

\section{INTRODUCTION}

\subsection{Research Background}

The global economy has begun with the introduction of the Asian Economic Community (MEA) which came into force on 31 December 2016. Creating a stable, prosperous and highly competitive Asean community is the goal of the MEA. Indonesia has a large population so that Indonesia becomes a target market for foreign countries to market their products to Indonesia.

In fact the development of the digital era can not be avoided internet users in Indonesia as much as 93.4 million people from 250 million population of Indonesia, and predicted next year will rise to 100 to 110 million people. The potential of this large market should not be abandoned. The Government's vision to make Indonesia as the country with the greatest economic growth in 2020 should be realized. If not, then Indonesia will be dominated by imported products. For example, China's MSMEs make Indonesia a target market. This means if within 2 years MSMEs are not included in the online market will be displaced by products from China and other countries.

East Java ranks second as a producer of UMKM products in Indonesia. Various efforts are made by the government to improve the ability of UMKM actors, either improving product quality through training, management and marketing of UMKM products. So that the products of SMEs East Java able to survive and compete in the era of MEA.

The economic growth of East Java can not be separated from the participation of UMKM. UMKM is one of the driving forces of economic growth in East Java. Gross Regional Domestic Product (PDRB) of East Java 2015 is about 1,690 trillion. Cooperatives and SMEs accounted for almost 20\%. By 2015 East Java's labor force total is 20 million people, while those working 19 million people. Of the 19 million people working in East Java 11 million work in the MSME sector. (Jatim Newsroom, 2016) Thus the number of unemployed in East Java can be reduced by the presence of SMEs.

The government through the Ministry of Communications and Informatics provides the program of one million Indonesian domains free of charge to schools, boarding schools, villages, and UMKM. Domain is a unique name given to identify the address (IP address) of a computer server such as a web server or email server on the internet. The target in 2016 is 350,000 Domains for four provinces. This one million ID program, not just provide facilities to get a free online store, but includes the literature of computer informatics technology so that ICT users can be more creative and productive. By using the domain or housting in the country is expected to save money, because MSMEs do not need to drive abroad for online store. 
East Java to get 60,000 Domains Indonesia for free which is used by SMEs East Java as capital for online business or penetrate a vast market without limit. This opportunity received a good reception from the perpetrators of SMEs, who continue to work hard to be able to compete and penetrate the broader market. The perpetrators of SMEs are fully aware of technological changes that can not be dammed. But the fact that happened in the field is constrained by the ability of SMEs in operating ICT operators, as well as lack of facilities and infrastructure to access the internet.

Based on the description above it can be concluded the importance of research on the constraints of the program a million domains Indonesia by limiting research only to SMEs East Java, and how the East Java government efforts to overcome them.

\subsection{Research Problem}

Based on these conditions show some of the problems identified in this study, namely the ability of ICT of the perpetrators of SMEs that the majority is very low, so many actors of SMEs are not able to operate the domain, and the lack of facilities and infrastructure SMEs actors to access the internet so that a constraint for online based marketing.

\subsection{Research Purpose}

By doing observation, data retrieval, as well as case study and literature, the authors do research with the objectives to be achieved as follows;

1. Identify problems that occur in the implementation of the program a million domains at SMEs East Java

2. Knowing the efforts of the government of East Java in overcoming the obstacles that occur in the implementation of a million domains Indonesia at SMEs East Java

3. Determining the priority of settlement to deal with all the problems that occur in the implementation of a million domains Indonesia at SMEs East Java

As for the benefit of this research is to give idea of thinking to problem faced by the perpetrator of UMKM East Java, so that implementation of UMKM go to online can be done well, so that will able to penetrate wider market and UMKM East Java able to compete in digital era.

\section{THEORETICAL FRAMEWORK}

\subsection{Theoretical Framework}

\subsubsection{UMKM}

According to Law Number 20 Year 2008: UMKM has the following criteria:

1. Micro Enterprises, ie productive businesses owned by individuals or business entities owned by individuals that meet the following criteria:

- Having a net worth of at most Rp 50,000,000 (fifty million rupiah) excluding land and building of business premises

- Have annual sales of at most Rp 3,000,000,000 (three hundred million rupiahs)

2. Small-scale business, which is a stand-alone productive economic enterprise undertaken by an Individual or a business entity which is not a subsidiary or non-owned subsidiary, is controlled or becomes a part of the direct or indirect business of a medium-sized or large-scale business that meets the criteria Namely:

- Having net worth of more than Rp50,000,000.00 (fifty million rupiah) up to a maximum of Rp500,000,000.00 (five hundred million rupiah) excluding land and building of business premises; or

- Having annual sales of more than Rp300,000,000.00 (three hundred million rupiahs) up to a maximum of Rp2,500,000,000.00 (two billion five hundred million rupiah).

3. Medium-sized enterprises, which are stand-alone productive economic enterprises, undertaken by individuals or business entities that are not subsidiaries or branches of a company owned, controlled, or become part directly or indirectly by small business or large business Criteria: 
- Having net worth of more than Rp500,000,000.00 (five hundred million copies) up to a maximum of Rp10,000,000,000.00 (ten billion rupiah) excluding land and building of business premises; or

- Has annual sales of more than Rp2,500,000,000.00 (two billion five hundred million rupiahs) up to a maximum of Rp50,000,000,000.00 (fifty billion rupiahs).

As according to the Central Bureau of Statistics (BPS) definition of SMEs is based on the quantity of labor. Small business is a business that has a workforce of 5 people samapai to 19 people, while the medium business is a business that has a workforce of 20 people up to 99 people.

According to the Ministry of Finance based on the Decree of the Minister of Finance No. $316 /$ KMK 016/1994 dated June 27, 1994, Small Business as an individual / business entity having activities / business that has sales / turnover per year as high as Rp. 600.000 .000 or asset (asset) as high as Rp.600.000.000 (excluding land and occupied buildings). For example Firma, CV, PT, and Cooperative in the form of business entities. While the example in the form of individuals, among others, craftsmen home industry, farmers, fishermen, merchants goods and services and others (http://infodanpengertian.blogspot.co.id/2015/04/pengertian-umkm-menurut-para-ahli. Html)

From various opinions above it can be concluded that the understanding of SMEs can be viewed from various angles, both in terms of wealth owned by the perpetrator, the amount of labor owned or in terms of sales / turnover of SMEs perpetrators.

According to Sri Winarni (2006) In general, small businesses have characteristics such as the following: (1) Usually in the form of individual business and not corporate legal entity, (2) Legality aspect of weak business, (3) Organizational structure is simple with division of work that is not (5) Low and rare management quality with a business plan, (6) The main source of business capital is personal capital, (7) Resources Human (HR) is limited, (8) The owner has a strong inner bond with the company, so that all the obligations of the company is also the obligation of the owner.

\subsubsection{Online Business}

Online business consists of 2 words of Business and Online. Business is a business or activity undertaken by groups and individuals, to earn profits by producing products and services to meet the needs of consumers. While the word Online by kamus.web.id is an activity connected through a computer network that can be accessed through other computer networks. So it can be concluded that Online Business is an activity or activities conducted in the internet media to make money. Just like a business activity in real life, online business that is run via the Internet also has the same goal that is generating a profit. (https://ariefdar.wordpress.com/2013/01/29/understanding-online-business/).

\subsubsection{Domain}

In today's digital era, domains have become commonplace accessible to many people, whether through computer media or through mobile devices such as mobile phones. Technological developments also require that the domain come to adjust, now hundreds of domain names can be found on the internet. The phenomenon now, the domain has adjusted to a country. For example, the Indonesian country domain name has the suffix .ID. Domain name (English: domain name) is a unique name given to identify the name of a computer server such as a web server or email server on a computer or internet network. Domain name serves to facilitate the user on the internet when accessing the server, but also used to remember the name of the server visited without having to know a row of complicated numbers known as IP addresses. This domain name is also known as a unity of a website such as "wikipedia.org" for example. Domain names are sometimes referred to as URLs, or website addresses. (Https://en.wikipedia.org/wiki/Nama_domain).

Basically, a Domain is a unique name, used instead of an IP Address. Domains are also referred to as Website Addresses, such as "solozine.com" or google.com "and others. The domains have formatting letters ( $\mathrm{a}, \mathrm{b}, \mathrm{c}$ and so on), numbers (1,2,3 and so on) and symbols (- ) As the website URL name.You can create a website address as you see fit, can use letters, numbers or symbols only. Basically, Domain Function is to facilitate internet users in accessing a website and make it easier to remember the address of the website to be accessed rather than having to use a series of complicated numbers called IP 
Addresses. As for example you want to access google.co.id website, if you use IP Address then you must access through a combination of numbers like 173.194.39.19, it will certainly make it difficult for internet users. Therefore there is a domain to provide convenience for internet users. (Http://www.solozine.com/2014/10/ domain.html).

\section{RESEARCH METHOD}

Research method in this research is qualitative method by using research sample as much as 150 perpetrator of UMKM, which follow program of one million domains. Everything comes from members of the association of SMEs East Java. This research was conducted from July to September 2016. Researcher digs information through direct observation, interview and Focus Group Discussion (FGD), to the perpetrators of UMKM.

\section{RESEARCH RESULT AND ANALYSIS}

In the 21st century, all sectors are experiencing integration with technological advances, the sector of East Java SMEs face a serious marketing challenge. Online-based marketing is becoming a growing trend among entrepreneurs. Based on data from the association of SMEs East Java, through interviews shows the level of awareness of the perpetrators of SMEs East Java to expand its marketing network through online media is very large, but it is hampered by several obstacles. The biggest obstacle is the perpetrators of UMKM can not operate the existing technology, and the lack of means and tools to access the online world.

This fact requires the government to be more active in fostering and providing facilities and facilities to facilitate internet access. Various efforts made by the government to solve the problems faced by the perpetrators of SMEs, the Government through the Office of Communications and Informatics East Java province in cooperation with the Department of Cooperatives and SMEs provide guidance and assistance for the perpetrators of SMEs. Among others, through the socialization in the form of training on the use of ICT, and filling website at the office of Kominfo East Java, as well as providing guidance and escort for the perpetrators of SMEs to be able to use and manage the website, so it is expected 60,000 Domain Indonesia program for East Java can be implemented in accordance with the goals and expectations, In example increasing sales of UMKM products 3 to 4 times. In connection with the facilities and infrastructure of Kominfo East Java in cooperation with Telkom to provide assistance facilities and infrastructure to some actors UMKM in the form of laptop and internet package for 3 months, Head of Communications and Information Technology of East Java province hope that the provision of facilities that can help the implementation of the program 1 million Indonesian domain, and For those who do not get the facilities hopefully able to provide their own facilities and infrastructure, however the JIUI will keep on guarding until the perpetrators of UMKM able to operate the website independently. The website filling and maintenance training program is done in the office of Kominfo Java gradually for the owners of the active domain, while the assistance is done through the region counselor for several cities. With the assistance to facilitate the perpetrators of SMEs to learn a lot to the nearest area counselor. Besides, it also uses social media as a means to communicate and consultation related to difficulties and obstacles in the implementation of domain usage. According to Menkominfo that Indonesia's economy is solid because there are SMEs. "Continue to struggle and continue to strive for the economy of the SME sector Ministry of Communications and Information Technology will help and support in providing infrastructure facilities to aims to accelerate the digital economy activity of SMEs," he said. Menkominfo emphasize to the perpetrators of SMEs about hosting, that is to sell products not just made (dot). Id but also have to process the image. There are labels and also information and can be accessible at any time of the community or who want to buy. "One year hosting provided from the Government is free and I am glad that the East Java Communications Service Office will create a datacentre. So, for East Java after a year free hosting can be transferred to Infocom East Java," said Rudiantara. 


\section{RESEARCH CONCLUSION AND RECOMMENDATION}

\subsection{Conclusion}

Recognizing the evolving technological change and the business world demand to follow the growth of ICT, forcing the government to improve the ability of UMKM to be UMKM based online so that SMEs East Java remain sustainable, Government through Department of Communications and Informatics East Java in cooperation with the Department of Cooperatives and SMEs continue to provide pengayoman To MSMEs through training, coaching and mentoring for SMEs East Java able to use 1 million domain facilities provided with appropriate and set targets can be achieved. Nevertheless the number of UMKM players with companions is less significant so that the program becomes slow.

\subsection{Recommendation}

a. The need for government cooperation for the mentoring program for example with the nearest educational institution, so that the program can be done quickly, and the acceleration of telecommunication infrastructure reach.

b. The need for active participation of the community, especially higher education to provide basic materials of ICT to the perpetrators of UMKM to help the implementation of the program 1 million domains.

\section{REFERENCES}

http://infodanpengertian.blogspot.co.id/2015/04/pengertian-umkm-menurut-para-ahli.html https://id.wikipedia.org/wiki/Nama_domain https://ariefdar.wordpress.com/2013/01/29/pengertian-bisnis-online/ http://www.solozine.com/2014/10/domain.html

Winarni, Sri. 2006. Strategi Pengembangan Usaha Kecil Melalui Peningkatan Aksesbilitas Kredit Perbankan. Infokom. Nomor 29 tahun XXII, 2006

*) Muhafidhah Novie, Nahdhatul Ulama University of Sidoarjo 